\title{
Stage Ois Ureter Cancer AJCC v7
}

National Cancer Institute

\section{Source}

National Cancer Institute. Stage Ois Ureter Cancer AJCC V7. NCI Thesaurus. Code C4529.

Stage Ois includes: T is, NO, MO. T is: Carcinoma in situ. N0: No regional lymph node metastasis. M0: No distant metastasis. (AJCC 7th ed.) 